\title{
Pengaruh Marketing Mix dan Customer Relationship Marketing melalui Keunggulan Bersaing dalam Meningkatkan Market Share Perbankan Syariah
}

\author{
Yusni Fadhilah', Lu'lu'il Maknuun', Ceta Indra Lesmana ${ }^{3}$ \\ ${ }^{1}$ Institut Pesantren KH.Abdul Chalim, Mojokerto, Indonesia \\ ${ }^{2}$ Institut Agama Islam Pangeran Diponegoro Nganjuk. Jl.Wilis Kramat,Nganjuk. \\ 3Institut Pesantren KH.Abdul Chalim, Mojokerto, Indonesia \\ E-mail: 'Yusnifadhilah1@gmail.com \\ E-mail: 2luluilmaknuun92@gmail.com
}

\begin{abstract}
Islamic banking has a market share problem which is still low compared to conventional banks. To increase market share, it is necessary to have the right strategy to excel in the competition. This study aimed to find out and interpret the influence of marketing mix and costumer relationship marketing through competitive advantage agains Islamic Banking market share. The research method used is a quantitative research method using primary data. The sample in this study is the Islamic Bank customers in Kediri. With sampling techniques using non-probability sampling. So the number of samples obtained as many as 190 respondents. Data analysis for this study used SEM models through tools smartPLS analysis 3.3.2. The results showed that the marketing mix had a significant effect on competitive advantage. Customer relationship marketing has a significant positive effect on competitive advantage. Competitive advantage has a significant positive effect on market share. Marketing mix has a significant positive effect on market share. Costumer relationship marketing has a significant positive effect on market share. The path test result prove that intervening competitive advantages is able to mediate the relationship between marketing mix and and costumer relationship marketing to Islamic banking market share.
\end{abstract}

Keywords : marketing mix, customer relationship marketing, competitive advantage, market share, Islamic banks

Abstraks:

Perbankan Syariah mengalami permasalahan market share yang masih rendah dibandingkan bank konvensional. Untuk meningkatkan market share perlu adanya strategi yang tepat untuk menjadi unggul dalam persaingan. Penelitian ini bertujuan untuk menganalisis dan menginterpretasikan pengaruh marketing mix dan costumer relationship marketing melalui keunggulan bersaing terhadap market share Perbankan Syariah. Metode penelitian yang digunakan dalam penelitian ini adalah metode penelitian kuantitatif dengan menggunakan data primer. Sampel pada penelitian ini adalah Nasabah Bank Syariah yang ada di Kediri. Dengan teknik pengambilan sampel menggunakan non probability sampling, sehingga diperoleh jumlah sampel sebanyak 190 responden. Analisis data pada penelitian ini menggunakan model SEM melalui alat analisis smartPLS 3.3.2

Hasil penelitian menunjukkan bahwa marketing mix berpengaruh signifikan terhadap keunggulan bersaing. Costumer relationship marketing berpengaruh postitif signifikan terhadap keunggulan bersaing. Keunggulan bersaing berpengaruh positif signifikan terhadap market share. Marketing mix berpengaruh positif signifikan terhadap market share. costumer relationship marketing berpengaruh positif signifikan terhadap market share. Hasil uji jalur membuktikan bahwa variabel intervening keunggulan bersaing mampu memediasi hubungan antara marketing mix dan costumer relationship marketing terhadap market share Perbankan Syariah.

Kata Kunci : Marketing Mix, Costumer Relationship Marketing (CRM), Keunggulan Bersaing, Market Share

\section{PENDAHULUAN}

Perbankan Syariah merupakan yang mulai beroperasi sejak salah satu lembaga keuangan syariah di Indonesia berdirinya Bank Muamalat Indonesia pada tahun 
1992. Kegiatan usaha bank syariah, baik dalam hal operasional, pengelolaan dan penyaluran dana dilaksanakan berdasarkan dengan prinsip syariah. Sesuai dengan Undang-Undang Republik Indonesia No.21 tahun 2008 tentang Perbankan syariah. Perbankan syariah adalah segala sesuatu yang menyangkut tentang Bank Syariah dan Unit Usaha Syariah, mecakup kelembagaan, kegiatan usaha, serta tata cara dan proses dalam melaksanakan kegiatan usahanya. Sedangkan Bank Syariah adalah Bank yang menjalankan kegiatan usahanya berdasarkan prinsip syariah dan menurut jenisnya terdiri atas Bank Umum Syariah dan Bank Pembiayaan Rakyat Syariah. Bank Umum Syariah adalah Bank Syariah yang dalam kegiatannya memberikan jasa dalam lalu lintas pembayaran. Sedangkan Unit Usaha Syariah adalah unit kerja dari kantor pusat Bank Umum Konvensional yang berfungsi sebagai kantor induk dari kantor atau unit yang melaksanakan kegiatan usaha berdasarkan prinsip syariah.

Sistem perbankan syariah yang dalam transaksi keuangannya beroperasi berdasarkan prinsip bagi hasil pada dasarnya ditujukan untuk memberikan alternatif sistem perbankan yang saling menguntungkan antara nasabah dan bank. Transaksi keuangan dengan mengedepankan aspek keadilan, etika dalam berinvestasi yang menggunakan nilai-nilai kebersamaan dan persaudaraan dilaksanakan untuk menghindari kegiatan spekulatif dalam bertransaksi. Dilaksanakan sesuai tujuan didirikannya bank syariah yaitu untuk menyediakan lalu lintas pembayaran sesuai dengan prinsip syariah sekaligus menghindari riba dan bunga bank konvensional di Indonesia. Bank syariah di Indonesia diharapkan dapat tumbuh dan berkembang dengan baik. Sehingga dapat dijadikan alternatif bagi masyarakat untuk memilih bank yang sesuai syariah Islam. Pertumbuhan perbankan syariah yang cukup baik, perlu dilakukan evaluasi yang lebih mendalam lagi terkait kinerja keuangannya. Sebagai salah satu indikator dari kinerja keuangan, market share menjadi penting untuk diperhatikan. Karena market share merupakan tolak ukur keberhasilan suatu perusahaan dalam mencapai tujuan perusahaan ${ }^{l}$.

Permasalahan pada perbankan syariah adalah market share yang sangat rendah. Hingga hingga tahun 2019 perbankan syariah hanya mampu menguasai 6,0\% market share terhadap perbankan nasional. Nilai yang sangat rendah dibandingkan dengan total market share yang dapat dicapai oleh perbankan konvensional. Bahkan pada bulan Maret 2020, market share turun dibandingkan dengan pencapaiannya pada akhir tahun 2019 yaitu diangka 5,99 \%. Perbankan syariah selain dinilai sangan minim market share-nya dibandingkan dengan perbankan konvensional juga mengalami perlambatan pada pertumbuhan market share. Dibuktikan dari nilai kinerjanya yaitu untuk menaikkan hingga 6\% perbankan syariah membutuhkan waktu bertahun tahun dari awal hadirnya perbankan syariah hingga sekarang ini. Hal ini dapat dijadikan kesimpulan bahwa selain market share yang minim, bank syariah juga mengalami stagnasi pertumbuhan market share.

1 De Siahaan, Usaha-usaha untuk mencapai target market share, (Universitas Diponegoro:2017), hlm 22 
Salah satu faktor penyebab keterlambatan dan stagnasi pertumbuhan market share perbankan syariah adalah perbandingan kinerja bisnis. Perbandingan Dana Pihak Ketiga, Pembiayaan Yang Disalurkan dan NPF perbankan syariah dengan perbankan konvensional masih memiliki gap yang sangat besar. Dalam hal ini peneliti ingin mengangkat perbankan syariah di Jawa Timur sebagai salah satu lokasi peneliti mengadakan penelitian ini.

Perbankan syariah di Jawa Timur pada tahun 2019 menempati posisi ke-3 seIndonesia dengan nilai asset terbesar diantara perbankan syariah di provinsi lain. Namun pada Maret-2020 posisi perbankan syariah di Jawa Timur menurun, dan menempati posisi ke-6 diantara perbankan syariah di Indonesia. Hal ini menunjukkan bahwa perbankan syariah di Jawa Timur mengalami penurunan prestasi.

Perkembangan bank syariah disisi kinerja DPK, PYD, dan NPF masih jauh dibandingkan dengan bank konvensional di Jawa Timur. DPK, PYD dan NPF Bank Syariah hanya sebesar 31.456, 28.826 dan 1.033 miliar dibandingkan dengan bank konvensional yaitu DPK sebesar 592.016, PYD sebesar 479.336 dan NPF sebesar 18.259. Hal ini menandakan bahwa bank Syariah belum mampu untuk menguasai pangsa pasar secara maksimal. Market share atau pangsa pasar bank syariah di Jawa Timur harus ditingkatkan untuk memperkecil gap yang terjadai dan memenangkan persaingan.

Tujuan market share adalah untuk melihat seberapa baik perusahaan mampu bersaing dibandingkan dengan perusahaan pesaingnya ${ }^{2}$. Perusahaan yang memiliki keunggulan bersaing yang tinggi akan mampu memperoleh posisi tertinggi sebagai leader dari para kompetitor di pasar yang sejenis. Begitu juga perusahaan yang belum mampu untuk menguasai market share yang tinggi, maka perlu memperhatikan kekuatan daya saing perusahaan dan melakukan evaluasi terhadap kinerja perusahaan. Dalam hal ini, dapat dilihat dari fakta yang ada perbankan syariah masih kalah dalam persaingan dengan bank konvensional. Sehingga perlua adanya strategi yang tepat untuk menjadi unggul dalam persaingan.

Keunggulan bersaing dapat meningkatkan market share perbankan syariah. Pernyataan ini sesuai dengan penelitian (L.Apriliani,2015) yang dalam penelitiannya menunjukkan adanya pengaruh yang signifikan variabel keunggulan bersaing terhadap market share. Berdasarkan hal tersebut, dalam penelitian ini peneliti menggunakan keunggulan bersaing sebagai salah satu variabel yang digunakan sebagai variabel intervening. Dan menguji pengaruh antara keunggulan bersaing terhadap market share.

Keunggulan bersaing dapat diciptakan dengan baik apabila perusahaan mampu membangun, memelihara dan mengembangkan berbagai keunggulan yang memiliki ciri khas perusahaan sebagai hasil dari beroperasinya berbagai asset

2 De Siahaan, Usaha-usaha untuk mencapai target market share, (Universitas Diponegoro:2017), hlm 20 
stratejik yang dimiliki dan dikembangkan perusahaan. ${ }^{3}$ Setiap perusahaan akan mampu menerapkan strategi-strategi bersaing seseuai dengan prinsip perusahaan. Dalam hal ini perbankan syariah dapat dinyatakan mampu untuk menerapkan strategi keunggulan tersebut, dilihat dari ciri khas prinsip utama perbankan yang berbeda dengan pesaingnya. Dengan melakukan inovasi dan menetapkan strategi yang tepat maka perbankan syariah dinilai akan mampu menguasai pasar perbankan nasional.

Penelitian yang telah dilakukan oleh (Heppy,2015) menyatakan bahwa kinerja bauran pemasaran dan manajemen kerelasian pelanggan berpengaruh secara simultan terhadap keunggulan bersaing Dalam penelitian (Endah, 2017) menyatakan bahwa terdapat pengaruh yang signifikan antara Costumer Relationship Marketing (CRM) terhadap keunggulan bersaing. Tetapi penelitian yang dilakukan oleh (Ndifor dan Ngambi, 2015) menunjukkan bahwa pengaruh Costumer Relationship Marketing (CRM) terhadap keunggulan bersaing adalah tidak signifikan. Oleh karena itu peneliti disini menggunakan variabel Costumer Relationship Marketing (CRM) sebagai salah satu variabel yang digunakan dalam penelitian ini.

\section{METODE PENELITIAN}

Penelitian ini menggunakan metode kuantitatif dengan melakukan analisis data menggunakan statistik. Penelitian yang ditujukan untuk menjawab masalah yang didapatkan melalui kajian empiris dan teoritis. Penelitian ini dilakukan pada bidang perbankan syariah yang ada di jawa timur. Khususnya mengenai strategi pemasaran bank syariah dalam meningkatkan market share. Penelitian berdasarkan atas tanggapan nasabah perbankan syariah melalui kuesioner tertutup yang telah dibuat oleh peneliti. Selanjutnya, penelitian ini dikerjakan dalam rentang waktu bulan Februari sampai Juni 2020. Jangka waktu tersebut digunakan untuk mengumpulkan tanggapan nasabah perbankan syariah dan mengolah hasil penelitian. Unit analisis dalam penelitian ini adalah nasabah perbankan syariah di Kediri, Jawa Timur.

Populasi dalam penelitian ini mengacu pada nasabah perbankan syariah yang berada di Jawa Timur. Namun karena berbagai alasan, penelitian ini hanya dilakukan terhadap sebagian populasi yang dinamakan sampel. Teknik pengambilan sampel mengunakan purposive sampling dengan proses penyebaran kuisioner penelitian dilakukan secara online dengan menggunakan google form. Purposive sampling adalah teknik penentuan sampel dengan pertimbangan tertentu. ${ }^{4}$ Dalam penelitian ini, peneliti memilih nasabah bank syariah yang berada di Kediri. Dalam penelitian yang akan dilakukan ini jumlah indikator sebanyak 19. Sehingga dengan menggunakan jumlah sampel minimal 10 kali dari jumlah variabel yang diteliti. ${ }^{5}$ Seperti dalam teori Roscoe tentang ukuran sampel untuk penelitian dapat diambil jumlah anggota sampel minimal 10 kali dari jumlah variabel yang

3 Apriany Prima Siregar, "Pengaruh Costumer Relationship Marketing Mangement dan Kualitas Strategi bisnis Terhadap Keunggulan Bersaing Dalam Meningkatkan Kinerja Unit”,Jurnal Sains Pemasaran Indonesia Vol XV, No.3,2016. Hlm. 197-198

${ }^{4}$ Prof.Dr.Sugiyono, hal.85.

${ }^{5}$ Prof.Dr.Sugiyono, hal.91. 
diteliti apabila penelitian akan melakukan analisis dengan multivariate. ${ }^{6}$ Maka dalam penelitian ini jumlah sampel yang dibutuhkan sebanyak 190 orang.

Adapun jenis dan sumber data dalam yang akan digunakan dalam penelitian ini adalah data primer. Data diperoleh langsung dari responden melalui hasil pengisian kuisioner. Sumber data primer yang digunakan dalam penelitian ini adalah data terkait persepsi responden mengenai marketing mix, costumer relationship marketing, keunggulan bersaing dan market share. Data yang digunakan selanjutnya adalah data sekunder sebagai data pelengkap yang diperoleh dari beberapa sumber bukum jurnal dan sumber informasi lain yang masih relevan dengan penelitian yang akan dilakukan. Dalam penelitian ini analisis data dilakukan dengan menggunakan pendekatan Structural Equation Model (SEM) yang dijalankan dengan menggunakan analisis statistic Partial Least Square (PLS). Peneliti memilih Structural Equation Model (SEM) karena penelitian yang akan dilakukan menggunakan permodelan persamaan struktural dengan memasukkan variabelvariabel yang tidak dapat diamati namun hanya diukur secara tidak langsung oleh indikator-indikator variabel pendukung atau variabel laten. ${ }^{7}$ Partial Least Square (PLS) dipilih oleh peneliti karena Partial Least Square (PLS) menggunakan metode bootstraping atau pengadaan secara acak dan tidak memerlukan data dengan asumsi normalitas dan juga tidak mensyaratkan jumlah minimum sampel. ${ }^{8}$

Setelah data terkumpul selanjutnya dilakukan analisis data untuk menjawab rumusan masalah dan menguji hipotesis. Hipotesis yang diuji dalam penelitian ini dapat dirumuskan sebagai berikut :

H1 :Marketing mix berpengaruh signifikan terhadap keunggulan bersaing. H2 :Costumer Relationship berpengaruh signifikan terhadap keunggulan bersaing.

H3 :Keunggulan bersaing berpengaruh signifikan terhadap market share. H4 :Marketing mix berpengaruh signifikan terhadap market share.

H5 : Costumer relationship berpengaruh signifikan terhadap market share

\section{HASIL DAN PEMBAHASAN}

${ }^{6}$ Prof.Dr.Sugiyono, hal.91.

7 Azuar Juliandi, Modul Pelatihan:Structural Equation Model Partial Least Square (SEM-PLS) dengan SMARTPLS, (Program Studi Administrasi Bisnis:Universitas Sumatera Utara,2018).hal.1

8 Ananda Sabil Hussein, Modul Ajar:Penelitian Bisnis dan Manajemen menggunakan Partial Least Square (PLS) dengan smartPLS 3.0,(Fakultas Ekonomi dan Bisnis:Universitas Brawijaya,2015), hal.2 
Responden dalam penelitian ini sebanyak 190 responden yang merupakan nasabah bank syariah. Responden diidentifikasikan dalam beberapa karakteristik. Karakteristik yang diidentifikasi dari responden dalam penelitian ini adalah jenis kelamin, usia, pendidikan terakhir, pekerjaan, rata-rata pendapatan perbulan, lama menjadi nasabah dan nama bank syariah responden.

Dari total 190 responden ditemukan bahwa 93 responden berjenis kelamin lakilaki dan 97 responden adalah perempuan. Dari sini dapat dilihat bahwa nasabah perempuan yang menjadi responden lebih banyak daripada nasabah perempuan dengan selisih angka sebanyak 4.

Menurut peneliti, perempuan memiliki lebih banyak kebutuhan dibandingkan dengan laki-laki. Dapat dicontohkan, bahwa perempuan lebih berpikir untuk mengelola dana demi memenuhi kebutuhan sehari-hari. Dalam hal ini dapat dijadikan pertimbangan perusahaan dalam meningkatkan promosi produk kepada masyarakat untuk meningkatkan market share.

Usia responden terdiri dari empat kategori yaitu usia 17 - 25 tahum, usia 26-30 tahun, usia 31-40 tahun dan usia lebih dari 51 tahun. Dari total 190 responden ditemukan bahwa 55 responden berusia $17-25$ tahun, 35 responden berusia 2630 tahun, 63 responden berusia 31-40 tahun dan 11 responden berusia lebih dari 51 tahun. Dari sini dapat dilihat bahwa responden yang berusia rentang $31-40$ dalam penelitian ini lebih banyak menjadi nasabah bank syariah dan menggunakan jasa bank syariah di Kediri.

Menurut peneliti, usia dapat memengaruhi daya beli masyarakat atau nasabah terhadap produk keuangan perbankan syariah. Usia 31-40 tahun merupakan usia produktif seseorang. Dalam usia produktif seseorang akan menjadi seorang pekerja dan mendapatkan penghasilan dari pekerjaannya. Dapat dicontohkan, alam usia tersebut seseorang akan mulai berpikir bagaimana dapat mengelola penghasilan yang didapat untuk dilakukan saving, hal ini dapat dimanfaatkan pihak pemasaran untuk lebih menajamkan strategi pemasarannya dan dapat meraih market share yang tinggi.

Menurut pendidikan terakhir responden terkategorikan menjadi lima. Dari total 190 responden ditemukan bahwa 8 responden memiliki pendidikan terakhir $<$ SMA/sederajat, 81 responden memiliki pendidikan terakhir SMA/sederajat, 11 responden memiliki pendidikan terakhir Diploma, 58 responden memiliki pendidikan terakhir Sarjana dan 32 responden memiliki pendidikan terakhir Pascasarjana. Berdasarkan data yang diperoleh peneliti, diketahui responden dengan pendidikan terakhir SMA/sederajat adalah paling banyak menjadi nasabah bank syariah. Hal ini dapat dikaitkan dengan banyaknya Sekolah Kejuruan yang ada di Kediri. Lulusan SMK memiliki semangat bekerja yang tinggi dengan bekal keahlian dan pengalaman yang diperoleh dari program magang. Lulusan SMA atau SMK yang telah bekerja akan melakukan transaksi keuangan misalnya untuk transfer gaji atau melakukan saving. Selain itu tidak menutup kemungkinan masyarakat yang memiliki pendidikan terakhir Sarjana yang dalam hal ini dinilai lebih mengetahui 
karakteristik bank syariah. Dilihat dari hasil responden dimana sarjana menempati posisi kedua terbesar. Hasil ini dapat menunjukkan bahwa pendiikan terakhir berpengaruh terhadap market share dalam segi pengetahuan dan kebutuhan yang dapat dijadikan pertimbangan perusahaan dalam memasarkan produk. Jenis pekerjaan responden terdiri dari lima kategori yaitu dokter/tenaga medis, guru/pegawai negeri/ABRI, karyawan BUMN/swasta, pengusaha/wiraswasta dan lainnya. Dari total 190 responden ditemukan bahwa 5 responden bekerja sebagai dokter/tenaga medis, 56 responden bekerja sebagai guru/pegawai negeri/ABRI, 98 responden bekerja sebagai karyawan BUMN/swasta, 27 responden bekerja sebagai pengusaha/wiraswasta dan 4 responden memiliki pekerjaan lain yaitu dalam penelitian ini sebagai petani. Dari sini dapat dilihat bahwa responden yang bekerja sebagai karyawan BUMN/swasta adalah yang paling banyak menjadi nasabah bank syariah dan menggunakan jasa keuangan perbankan syariah. Dari hasil diatas, menurut peneliti, nasabah bank syariah adalah paling banyak memiliki pekerjaan sebagai karyawan. Dalam hal ini nasabah yang menjadi karyawan swasta/BUMN dinilai lebih sering menggunakan layanan jasa keuangan perbankan syariah. Contohnya adalah digunakan sebagai transfer gaji, tabungan dan pembiayaan konsumen. Hal ini berpengaruh kepada market share perbankan syariah, apabila nasabah yang bekerja sebagai karyawan swasta/BUMN dapat ditingkatkan kuantitasnya oleh bank syariah. maka hal ini dapat menambah transaksi keuangan dalam hal penyimpanan dana, penyaluran dana untuk kebutuhan lebih dari nasabah dan transaksi jasa yang dalam setiap bulan pasti akan dilakukan transaksi.

Dari total 190 responden ditemukan bahwa 4 responden memiliki rata-rata penghasilan kurang dari 1 juta, 67 responden memiliki rata-rata penghasilan 1-3 juta, 104 responden memiliki rata-rata penghasilan 3-5 juta, 14 responden memiliki rata-rata penghasilan 5-7 juta dan 1 responden memiliki rata-rata penghasilan 7-10 juta. Dari sini dapat dilihat bahwa responden yang memiliki rata-rata penghasilan 3-5 juta lebih banyak menjadi nasabah bank syariah dan menggunakan jasa keuangan perbankan syariah.

Hal ini berkaitan dengan tingkat kebutuhan masyarakat atas transaksi keuangan bank syariah. Berdasarkan data karakteristik pekerjaan responden. Diperoleh bahwa responden yang paling banyak adalah karyawan. Dapat dihubungkan dengan penghasilan responden disini bahwa rata-rata masyarakat yang bekerja sebagai karyawan dan yang memiliki penghasilan 3-5 juta paling banyak menjadi nasabah di bank syariah. berdasarkan data yang diperoleh ini dapat digunakan sebagai pertimbangan target pasar dalam hal promosi untuk dapat meningkatkan market share.

Dari total 190 responden ditemukan bahwa 15 responden telah menjadi nasabah selama $<6$ bulan, 2 responden telah menjadi nasabah selama 6-1 tahun, 75 responden telah menjadi nasabah selama 1 tahun-3 tahun, 35 responden telah menjadi nasabah selama 3-5 tahun dan 63 responden telah menjadi nasabah 
selama lebih dari 5 tahun. Dari sini dapat dilihat bahwa responden yang telah menjadi nasabah selama kurun waktu 1-3 tahun adalah yang paling banyak. Nama bank syariah responden yang didapat dari penyebaran kuesioner dikategorikan menjadi 7 kategori. Dari total 190 responden ditemukan bahwa 6 responden menjadi nasabah Bank Jatim, 51 responden menjadi nasabah Bank Mandiri Syariah, 13 responden menjadi nasabah Bank Mega Syariah, 13 responden menjadi nasabah Bank Muamalat, 3 responden menjadi nasabah Bank Sinarmas, 14 responden menjadi nasabah BNI Syariah dan 92 responden menjadi nasabah Bank BRI Syariah. Dari sini dapat dilihat bahwa responden yang paling banyak merupakan nasabah Bank BRI Syariah.

Data yang dihasilkan dalam penelitian ini merupakan data primer yang diperoleh langsung melalui pengisian kuesioner oleh nasabah bank syariah yang ada di Kediri. Data yang telah di tabulasi selanjutnya dianalisis menggunakan model SEM melalui alat analisis smartPLS 3.3.2. hasil uji analisa hipotesis adalah sebagai berikut :

\section{Marketing mix berpengaruh signifikan terhadap keunggulan bersaing} Hipotesis pertama adalah marketing mix berpengaruh signifikan terhadap keunggulan bersaing. Hasil pengujian menunjukkan bahwa nilai original sampel CRM terhadap keunggulan bersaing sebesar 0,410 yang menunjukkan arah pengaruh positif dan nilai t-statistik sebesar 6,871. Dari hasil tersebut dapat dinyatakan nilai $\mathrm{t}$-statistik adalah signifikan, karena $>1,96$ dengan $\mathrm{p}$-value $<0,05$ sehingga hipotesis pertama diterima. Hal tersebut membuktikan bahwa marketing mix berpengaruh signifikan terhadap keunggulan bersaing. Bank Syariah di Kediri mampu menciptakan strategi marketing mix yang tepat untuk memperoleh keunggulan bersaing. Hal ini dibuktikan dari jawaban responden yang menghasilkan nilai tertinggi pada aspek pelayanan. Dalam hal ini dapat disimpulkan bahwa nasabah bank syariah di Kediri merasa puas akan pelayanan yang diberikan bank syariah di Kediri. Seperti yang diketahui bahwa Bank Syariah memberikan pelayanan dengan mengutamakan etika dan kesopanan. Hal ini menjadi ciri khas sendiri dari bank syariah yang apabila dapat diterapkan dan dikembangkan maka akan menjadi salah satu keunggulan tersendiri bagi bank syariah.

Hasil yang diperoleh sesuai dengan sebuah literatur dr (Dimas, 2015) dalam penelitiannya yang menyatakan bauran pemasaran sebagai salah satu bentuk strategi pemasaran merupakan salah satu cara untuk memenangkan keunggulan bersaing dalam memenangkan persaingan. Sebagai contoh, salah satu indikator marketing mix adalah promosi, ketika bank syariah dapat mempromosikan produknya secara maksimal kepada masyarakat sehingga masyarakat akan lebih banyak mengenal produk bank syariah dibandingkan dengan bank konvensional, hal ini mampu meningkatkan keunggulan bersaing dalam aspek pionir. 


\section{Costumer relationship marketing (CRM) berpengaruh signifikan terhadap keunggulan bersaing}

Hipotesis kedua adalah costumer relationship marketing (CRM) berpengaruh signifikan terhadap keunggulan bersaing. Hasil pengujian menunjukkan bahwa nilai original sampel CRM terhadap keunggulan bersaing sebesar 0,550 yang menunjukkan arah pengaruh positif dan nilai t-statistik sebesar 9,569. Dari hasil tersebut dapat dinyatakan nilai t-statistik adalah signifikan, karena $>1,96$ dengan p-value $<0,05$ sehingga hipotesis kedua diterima. Hal tersebut membuktikan bahwa costumer relationship marketing (CRM) berpengaruh signifikan terhadap keunggulan bersaing.

Bank syariah di Kediri telah menerapkan strategi CRM dengan baik yang memiliki dampak kepada kepuasan nasabahnya sehingga dapat memberikan nilai keunggulan bersaing tersendiri. CRM menekankan pada pemenuhan kebutuhan dan keinginan nasabah. Dimana dalam penelitian ini responden memberikan pernyataan setuju pada setiap item indikator CRM. Hal ini dapat disimpulkan bahwa CRM yang diterapkan oleh bank Syariah apabila dilakukan dengan baik akan meningkatkan keunggulan bersaing.

Hasil yang diperoleh sesuai dengan sebuah literatur dr Munandar yang dikutip oleh Agitia Rahmawati dalam penelitiannya menyatakan bahwa costumer relationship marketing (CRM) merupakan strategi komprehensif dan proses untuk memperoleh, mempertahankan dan bermitra dengan para pelanggan tertentu untuk menciptakan nilai keunggulan bagi perusahaan dan pelanggan. Sebagai contoh, apabila bank syariah menerapkan pelayanan dimana setiap karyawan diharuskan bersikap ramah dan sopan kepada nasabah dan mampu memahami serta menangani keluhan nasabah secara individual, hal ini mampu meningkatkan keunggulan bersaing dari aspek pelayanan.

Keunggulan bersaing berpengaruh signifikan terhadap market share Hipotesis ketiga adalah keunggulan bersaing berpengaruh signifikan terhadap market share. Hasil pengujian menunjukkan bahwa nilai original sampel keunggulan bersaing terhadap market share sebesar 0,478 dan nilai t-statistik sebesar 4,452. Dari hasil tersebut dapat dinyatakan nilai t-statistik adalah signifikan karena $>1,96$ dengan $\mathrm{p}$-value $<0,05$ sehingga hipotesis ketiga diterima. Hal tersebut membuktikan bahwa keunggulan bersaing berpengaruh signifikan terhadap market share.

Pengukuran keunggulan bersaing Bank Syariah di Kediri dalam penelitian ini berdasarkan penilaian dari nasabah. Dari jawaban responden nasabah banyak yang setuju jika produk yang ditawarkan bank syariah membebankan biaya administrasi yang kompetitif dibandingkan dengan bank lain. Hal ini dapat menjadi pertimbangan pihak perusahaan bahwa dalam menciptakan keunggulan bersaing khususnya menciptakan produk produk keuangan harus memperhatikan aspek 
harga yang murah. Selain itu pelayanan yang memiliki ciri khas dari perbankan syariah harus selalu dipertahankan dan terus ditingkatkan untuk menciptakan keunggulan bersaing yang lebih tinggi dibandingkan dengan bank lainnya. (Lydia, 2015) menyatakan bahwa pencapaian keunggulan bersaing dapat dianggap sebagai keberhasilan perusahaan dalam meningkatkan market share. Sebagai contoh, apabila bank syariah memiliki keunggulan bersaing dalam aspek harga yang murah dibandingkan dengan pesaing khususnya bank konvensional, maka masyarakat akan lebih memilih untuk menggunakan jasa yang ditawarkan bank syariah, semakin banyak nasabah yang menggunakan jasa bank syariah maka akan meningkatkan market share bank syariah itu sendiri.

Marketing mix berpengaruh signifikan terhadap market share Hipotesis keempat adalah marketing mix berpengaruh signifikan terhadap market share. Hasil pengujian menunjukkan bahwa nilai original sampel marketing mix terhadap market share sebesar 0,171 dan nilai t-statistik sebesar 2,095. Dari hasil tersebut dapat dinyatakan nilai t-statistik adalah signifikan karena $>1,96$ dengan pvalue $<0,05$ sehingga hipotesis keempat diterima. Hal tersebut membuktikan bahwa marketing mix berpengaruh signifikan terhadap market share. Besarnya market share yang ditentukan dapat diraih dengan bergantung pada kualitas penerapan strategi pemasarannya. Sebagai contoh, apabila bank syariah melakukan promosi secara maksimal kepada masyarakat maka masyarakat akan lebih mengenal dan tertarik untuk melakukan transaksi keuangan pada bank syariah. Sehingga bank syariah mampu memperoleh pasar yang lebih luas dan meningkatkan nilai market share termasuk total penghimpunan dana, penyaluran dana dan transaksi jasa lainnya.

Hasil tersebut sesuai dengan sebuah literature dari Kotler yang menyatakan bahwa market share dapat ditingkatkan melalui pendekatan marketing mix. Hal ini dapat dilakukan melalui pencipataan produk yang sesuai dengan kebutuhan masyarakat dan nasabah. Mengoptimalkan pemasaran dan memperluas jangkauan pemasaran. Serta meningkatkan pelayanan, karena pelayanan yang semakin baik akan memberikan efek kepuasan kepada nasabah, dan nasabah yang merasa puas akan terus menggunakan layanan bank syariah sehingga dapat mempertahankan market share yang telah dicapai.

\section{Costumer Relationship Marketing (CRM) berpengaruh signifikan terhadap market share}

Hipotesis kelima adalah costumer relationship marketing berpengaruh signifikan terhadap market share. Hasil pengujian menunjukkan bahwa nilai original sampel costumer relationship marketing terhadap market share sebesar 0,271 menunjukkan arah pengaruh positif dan nilai t-statistik sebesar 2,831. Dari hasil tersebut dapat dinyatakan nilai t-statistik adalah signifikan karena $>1,96$ dengan pvalue $<0,05$ sehingga hipotesis kelima diterima. Hal tersebut membuktikan 
bahwa costumer relationship marketing berpengaruh signifikan terhadap market share.

Menurut (Alihasan, 2017) penerapan CRM memberikan dampak positif pada market share. Dampak terbesar CRM adalah pada terciptanya nasabah yang loyal. Nasabah yang loyal akan memberikan peningkatan pada konsumsi jasa bank syariah yang dapat berkontribusi dalam peningkatan market share bank syariah. Hasil tersebut sesuai dengan literature yang didapat dari penelitian (Ali Hasan, 2017) yang berjudul power relationship marketing dalam bisnis. Dalam penelitiannya menyatakan bahwa relationship marketing merupakan sebuah strategi untuk membangun hubungan jangka panjang dengan menggunakan pengaruh jaringan pasar untuk memahami kebutuhan dengan cara menawarkan kepada konsumen, jika konsumen merasa puas maka akan memiliki keinginan lebih untuk membeli kembali. Keinginan ini secara tidak langsung akan mempertahankan dan meningkatkan market share yang telah ditentukan

\section{KESIMPULAN}

Dari hasil analisis data dan pembahasan yang telah dipaparkan maka dapat diambil kesimpulan sebagai berikut:

1. Berdasarkan hasil pengujian menunjukkan bahwa variabel marketing mix berpengaruh positif signifikan terhadap keunggulan bersaing perbankan syariah. Bank Syariah di Kediri mampu menciptakan strategi marketing mix yang tepat untuk memperoleh keunggulan bersaing. Hal ini dibuktikan dari jawaban responden yang menghasilkan nilai tertinggi pada aspek pelayanan.

2. Berdasarkan hasil pengujian menunjukkan bahwa variabel costumer relationship marketing (CRM) memiliki berpengaruh positif signifikan terhadap keunggulan bersaing. Hal ini dapat disimpulkan bahwa CRM yang diterapkan oleh bank Syariah apabila dilakukan dengan baik akan meningkatkan keunggulan bersaing.

3. Berdasarkan hasil pengujian menunjukkan bahwa variabel keunggulan bersaing memiliki berpengaruh positif signifikan terhadap keunggulan bersaing.

4. Berdasarkan hasil pengujian menunjukkan bahwa variabel marketing mix memiliki pengaruh positif yang signifikan terhadap market share.

5. Berdasarkan hasil pengujian menunjukkan bahwa variabel costumer relationship marketing (CRM) berpengaruh positif signifikan terhadap market share.

6. Berdasarkan hasil uji jalur. Hasil pengujian menunjukkan bahwa keunggulan bersaing mampu memediasi pengaruh marketing mix terhadap market share. Dari hasil yang diperoleh dapat disimpulkan bahwa keunggulan bersaing mampu memediasi pengaruh marketing mix terhadap market share. Dapat diartikan bahwa untuk memperoleh market share yang tinggi perusahaan 
harus menggunakan memperhatikan aspek keunggulan bersaing dalam penerapan strategi pemasaran marketing mix.

7. Berdasarkan hasil uji jalur. Hasil pengujian menunjukkan bahwa keunggulan bersaing mampu memediasi pengaruh costumer relationship marketing terhadap market share. Dari hasil yang diperoleh dapat disimpulkan bahwa keunggulan bersaing mampu memediasi pengaruh costumer relationship marketing terhadap market share. Dapat diartikan bahwa untuk memperoleh market share yang tinggi perusahaan harus menggunakan aspek keunggulan bersaing dalam penerapan strategi pemasaran costumer relationship marketing.

\section{UCAPAN TERIMA KASIH}

Untuk dapat menyelesaikan penelitian ini, penulis mendapatkan berbagai bantuan dari beberapa pihak. Oleh karena itu penulis berkewajiban menyampaikan rasa terima kasih sedalam-dalamnya, terutama kepada: Rektor Institut Agama Islam Pangeran Diponegoro (IAI PD) Nganjuk dan Institut Pesantren KH.Abdul Chalim, Mojokerto, Indonesia yang telah memberikan izin kepada penulis untuk dapat menyelesaikan studi akhir. Dekan Fakultas Syariah dan Ekonomi Islam, yang telah memberikan izin dan pengarahan pada peneliti.

\section{DAFTAR RUJUKAN}

Amir, Muhammad Nur Fauzi.2018. "Pengaruh Pelanggan, kepuasan nasabah,kualitas pelayanan, dan relationship marketing terhadap loyalitas nasabah". Dalam skripsi S1. Jakarta: UIN Syarif Hidayatullah.

Amstrong, Gary, dan Philip Kotler. 2001. “Prinsip-Prinsip Pemasaran”. Jakarta: Erlangga.

Apriliani, Lydia. 2015. "Faktor-faktor yang Mempengaruhi Keunggulan Bersaing dalam Upaya Meningkatkan Market Share" dalam skripsi S1. Semarang: Universitas Diponegoro.

Astuty.Widya. 2018. "Pengaruh Strategi Bauran Pemasaran dan Keunggulan Bersaing terhadap Pangsa Pasar Industri Kecil Pengolahan ikan di Sumatera Barat".dalam Jurnal Riset Akuntansi dan Bisnis ISSN 1693-7579. Fakultas Ekonomi Universitas Muhammadiyah Sumatera Utara.

Azizah, Umi, dan Ida Mafrukhah. 2017."Pengaruh kemitraan dan orientasi pelanggan terhadap kinerja pemasaran melalui keunggulan bersaing. dalam Jurnal: management analysis journal 6 Vol 2 . Universitas Negeri Semarang

Budiarti, Endah.,dkk. 2018. "Effect of costumer relationship management, marketing mix, service quality, enterpreneurs orientation to competitive advantages and its impact on marketing performance at public market" dalam Archives of business research Vol.6, No.8I. Society for science and education.

Budiarti,Endah. "Pengaruh customer relationship management, kualitas pelayanan, orientasi kewirausahaan terhadap keunggulan bersaing dan dampaknya pada kinerja pemasaran pasar rakyat di provinsi jawa timur. Dalam Seminar hasil penelitian dan pengabdian masyarakat Hasil Riset dan Pengabdian Masyarakat sebagai inovasi menuju persaingan global ISBN.978-602-53170-2-6. Universitas 17 Agustus 1945 Surabaya

Chadiq, Umar. "Costumer relationship Management (CRM): Pilihan strategi untuk meraih keunggulan bersaing". Fakultas Ekonomi Unwahas Semarang

Cornelia, Bella Risma Adelberta.2019."Analisis Pelaksanaan Strategi Pemasaran terhadap Keunggulan Bersaing” dalam skripsi S1. Sumatera Utara: Universitas Sumatera Utara. 
Hajar, Siti dan I Putu Gede. 2016. "Peran Keunggulan Bersaing memediasi pengaruh orientasi kewirausahaan terhadap kinerja pemasaran" dalam E Jurnal Manajemen Unud Vol.5 No.10 ISSN:2302-8912. Universitas Udayana.

Hermawan Kertajaya, 2007, "Hermawan Kertajaya on marketing mix”,Bandung :Mizan Pustaka.

Hermawan Kertajaya, 2006, "Boosting Field Marketing Performance”, Bandung: Mizan Pustaka.

Hermawan Kertajaya, 2007, "Hermawan Kertajaya on Selling”, Bandung: Mizan. Hussein, Ananda Sabil. 2018. "Modul Ajar: Penelitian Bisnis dan Manajemen menggunakan Partial Least Square (PLS) dengan SmartPLS 3.0” Universitas Brawijaya

Indah, Dewi Purnama dan Devie. "Analisa Pengaruh Costumer Relationship Management terhadap keunggulan bersaing dan Kinerja Pemasaran" dalam Jurnal Akuntansi Bisnis. Universitas Kristen Petra.

Jayaningrum, Erni dan Brillyanes Sanawiri. 2018. "Pengaruh Orientasi Pasar, Inovasi, Orientasi Kewirausahaan terhadap Keunggulan Bersaing dan Kinerja Pemasaran" dalam Jurnal Administrasi Bisnis Vol.54 No.1 Januari 2018. Universitas Brawijaya.

Juliandi, Azuar.2015. "Modul Pelatihan: Structural Equation Model Partial Least Square (SEM-PLS) dengan SmartPLS". Universitas Brawijaya. Kotler, Philip. 2005. "Majanemen Pemasaran". Jakarta: Gramedia.

Keuangan, Otoritas Jasa. Statistik Perbankan Syariah. www.ojk.go.id, diakses pada September 2019

Ratnasari, Ririn Tri, dan Mastuti. 2016. "Manajemen Pemasaran Jasa". Bogor: Ghalia Indonesia.

Sugiyono. 2017. "Metode Penelitian". Bandung: Alfabeta. Sugiyono. 2017. "Metode Penelitian Kuantitatif Kualitatif dan $R \& D$ ". Bandung:Alfabeta

Zainal, Veithzal Rivai, dan dkk. 2017. "Islamic Marketing Management”. Jakarta: PT Bumi Aksara. 